\title{
ANALISIS POTENSI PENYEBAB RUMAH TANGGA MISKIN JAWA TENGAH
}

\author{
Laeli Sugiyono, Sriningsih
}

BPS Provinsi Jawa Tengah

Email: laeli @bps.go.id, srining@bps.go.id

\begin{abstract}
Abstrak
Penelitian ini bertujuan menganalisis potensi penyebab rumah tangga miskin di Jawa Tengah. Analisis menggunakan regresi logistik. Penelitian menggunakan data sekunder hasil Survei Sosial Ekonomi Nasional (Susenas) di Jawa Tengah 2018 yang dikumpulkan oleh Badan Pusat Statistik. Penelitian menyimpulkan bahwa ada 5 karakteristik utama, yaitu daerah tempat tinggal, gender, jenjang pendidikan, jumlah anggota rumah tangga dan status bekerja kepala rumah tangga, yang berpotensi menyebabkan kemiskinan rumah tangga di Jawa Tengah. Rumah tangga yang tinggal di daerah perdesaan mempunyai peluang menjadi miskin 1,398 kali lebih tinggi dari pada daerah perkotaan. Atas dasar itu, perlu adanya prioritas pembangunan di wilayah perdesaan.
\end{abstract}

Kata kunci: potensi penyebab, rumah tangga miskin, regresi logistik

\begin{abstract}
This study aims to analyze the potential causes of poor households in Central Java. Analysis using logistic regression. The study used secondary data from the National Socio-Economic Survey (Susenas) in Central Java 2018 collected by Badan Pusat Statistik. The study concluded that there are 5 main characteristics, namely the area of residence, gender, education level, number of household members and the status of working head of household, which has the potential to cause household poverty in Central Java. Households living in rural areas have the opportunity to be poor at 1,398 times higher than in urban areas. On that basis, there needs to be development priorities in rural areas.
\end{abstract}

Keywords: potential causes, poor households, logistic regression. 


\section{PENDAHULUAN}

Pembangunan ekonomi pada dasarnya merupakan perwujudan proses multidimensi yang melibatkan perubahan struktur mendasar dalam barbagai hal, antara lain: sosial, sikap masyarakat, dan kelembagaan. Proses pembangunan yang terjadi misalnya adalah percepatan pertumbuhan ekonomi, pengurangan dan penanggulangan penduduk miskin dan ketimpangan sosial (Todaro, 2003).

Kemiskinan diketahui sebagai permasalahan yang kompleks, dimana melibatkan faktor-faktor yang saling berkaitan, antara lain: tingkat pendapatan, kesehatan, pendidikan, akses terhadap barang dan jasa, lokasi geografis, gender dan kondisi lingkungan. Kompleksnya permasalahan kemiskinan ini, membuat upaya pengentasan kemiskinan akan terasa cukup sulit. Berbagai penanggulangan kemiskinan menjadi agenda penting pembangunan dalam mewujudkan kesejahteraan masyarakat. (Bappenas, 2000).

Pada bulan September 2000, dibangun di atas satu dasawarsa konferensi dan KTT besar PBB, para pemimpin dunia berkumpul di Markas Besar PBB di New York untuk mengadopsi Deklarasi Milenium PBB. Deklarasi mengikat negaranegara pada kemitraan global baru untuk mengurangi kemiskinan ekstrem, dan menetapkan serangkaian delapan target terikat waktu - dengan tenggat waktu 2015 - yang dikenal sebagai Tujuan Pembangunan Milenium (MDGs). (United Nations, 2015).

Agenda 2030 untuk Pembangunan Berkelanjutan, yang diadopsi oleh semua Negara Anggota Perserikatan BangsaBangsa pada tahun 2015, memberikan cetak biru bersama untuk perdamaian dan kemakmuran bagi manusia dan planet ini, sekarang dan di masa depan. Pada intinya adalah 17 Tujuan Pembangunan Berkelanjutan (SDGs), yang merupakan seruan mendesak untuk bertindak oleh semua negara - maju dan berkembang dalam kemitraan global. Mereka menyadari bahwa mengakhiri kemiskinan dan perampasan lainnya harus berjalan seiring dengan strategi yang meningkatkan kesehatan dan pendidikan, mengurangi ketimpangan, dan memacu pertumbuhan ekonomi - semuanya sambil mengatasi perubahan iklim dan bekerja untuk melestarikan lautan dan hutan kita. (Erwandari, 2017).

Berdasarkan latar belakang tersebut, maka perlu diidentifikasi potensi penyebab rumah tangga miskin di Jawa Tengah. Dengan diketahuinya potensi penyebab rumah tangga miskin tersebut, maka strategi pembangunan yang dilakukan baik oleh pemerintah pusat maupun pemerintah daerah dalam mengurangi kemiskinan lebih tepat, efektif dan efisien. Berdasarkan pada kondisi yang ada, maka penelitian ini bertujuan menganalisis potensi penyebab rumah tangga miskin Jawa Tengah.

\section{METODE}

\section{Model Analisis}

Regresi logistik merupakan pendekatan untuk membuat model prediksi seperti pada regresi linear atau Ordinary Least Squares (OLS) regression. Namun pada regresi logistik, peneliti memprediksi probabilitas variabel (Y) yang berskala dikotomi. Skala dikotomi yang dimaksud ialah skala data nominal dengan dua kategori, misalnya: Ya dan Tidak.

Regresi Binari Logistik tidak memerlukan uji normalitas untuk menganalisis hasil pada variabel bebasnya karena variabel terikatnya adalah variabel dummy. Residual Regresi Binari Logistik dapat diartikan sebagai selisih antara nilai prediksi dengan nilai sebenarnya yang tidak perlu lagi dilakukan uji normalitas. Regresi Binari Logistik juga tidak memerlukan heteroscedasticity, sehingga variabel terikat tidak memerlukan homoskedasitas (homoscedasticity) untuk masing-masing variabel bebasnya (Gujarati, 2003).

Perumusan model binary logistik regresi yang digunakan adalah: 


$$
\begin{aligned}
\log \left(\frac{p_{i}}{1-p_{i}}\right)_{i}= & \alpha_{0}+\beta_{1} X_{1 i}+\beta_{2} X_{2 i}+\beta_{3} X_{3 i} \\
& +\beta_{4} X_{4 i}+\beta_{5} X_{5 i}+\beta_{6} X_{6 i}+\varepsilon_{i}
\end{aligned}
$$

Di mana:

$\mathrm{p}=$ probabilitas miskin, $1-\mathrm{p}=$ probabilitas tidak miskin, $\mathrm{p} /(1-\mathrm{p})$ odds

$\mathrm{X} 1 \mathrm{i}=$ Daerah Tempat Tinggal dengan kategori: $0=$ Perkotaan $1=$ Perdesaan .

$\mathrm{X} 2 \mathrm{i}=$ Gender Kepala Rumah Tangga dengan kategori: $0=$ Laki-laki, $1=$ Perempuan.

$\mathrm{X} 3 \mathrm{i}=$ Jenjang Pendidikan Kepala Rumah

Tangga dengan kategori:

0 = Tamat SMP dan Sederajat atau yang lebih.

$1=$ Tamat SD dan Sederajat atau lebih rendah. tinggi.

$\mathrm{X} 4 \mathrm{i}=$ Usia kepala rumah tangga dengan

kategori:

$0=$ Muda (Dibawah 60 tahun).

$1=$ Tua ( 60 tahun atau lebih).

$\mathrm{X} 5 \mathrm{i}=$ Anggota rumah tangga, dengan kategori:

$0=$ beranggotakan satu sampai empat,

$1=$ beranggotakan lima dan atau lebih.

$\mathrm{X} 6 \mathrm{i}=$ Status Ketenagakerjaan kepala

rumah tangga, dengan kategori

$1=$ Bekerja, $0=$ Tidak Bekerja.

$\beta 1, \beta 2, \beta 3, \beta 4, \beta 5=$ Koefisien regresi

$\varepsilon_{i}=$ suku kesalahan (error term)

$\mathrm{i}=1, \ldots, \mathrm{n}$ (data pada rumah tangga).

\section{Signifikansi Model}

Untuk mengetahui pengaruh variabel bebas terhadap variabel tidak bebas secara bersama-sama (overall) di dalam model, dapat menggunakan Uji Likelihood Ratio. Hipotesisnya adalah sebagai berikut:

Ho: $\beta 1=\beta 2=\ldots=\beta p=0$ (tidak ada pengaruh veriabel bebas secara simultan terhadap kemiskinan)

$\mathrm{H} 1$ : minimal ada satu $\beta \mathrm{j} \neq 0$ (ada pengaruh paling sedikit satu veriabel bebas terhadap kemiskinan)

Untuk $\mathrm{j}=1,2, \ldots, \mathrm{p}$

Statistik uji yang digunakan adalah: $G^{2}=-2 \ln \frac{L_{0}}{L_{p}}$

Dengan :
Lo = Maksimum Likelihood dari model reduksi (Reduced Model) atau model yang terdiri dari konstanta saja

Lp = Maksimum Likelihood dari model penuh (Full Model) atau dengan semua variabel bebas.

Statistik G2 ini mengikuti distribusi Khikuadrat dengan derajad bebas $p$ sehingga hipotesis ditolak jika $\mathrm{p}$-value $<\alpha$, yang berarti variabel bebas $\mathrm{X}$ secara bersamasama mempengaruhi variabel tak bebas $\mathrm{Y}$

\section{Nilai Odds Ratio}

Pada umumnya, tujuan analisis statistik adalah untuk mencari model yang cocok dan keterpautan yang kuat antara model dengan data yang ada. Pengujian keberartian parameter (koefisien $\beta$ ) secara parsial dapat dilakukan melalui Uji Wald dengan hipotesisnya sebagai berikut:

Ho: $\beta \mathrm{j}=0$ (variabel bebas ke $\mathrm{j}$ tidak mempunyai pengaruh secara signifikan terhadap variabel tidak bebas)

$\mathrm{H} 1: \beta \mathrm{j} \neq 0$ (variabel bebas ke $\mathrm{j}$ mempunyai pengaruh secara signifikan terhadap variabel tidak bebas)

Untuk $\mathrm{j}=1,2, \ldots, \mathrm{p}$

Dengan statistik uji sebagai berikut:

$W=\left[\frac{\beta_{j}}{\operatorname{Se}\left(\beta_{j}\right)}\right]^{2}$

Hipotesis ditolak jika $\mathrm{p}$-value $<\alpha$ yang berarti variabel bebas $\mathrm{Xj}$ secara partial mempengaruhi variabel tidak bebas $\mathrm{Y}$.

\section{Kerangka Pikir Pemilihan Variabel bebas yang berpengaruh}

Dalam melakukan kajian potensi penyebab kemiskinan rumah tangga sebagai variabel terikat dalam analisis regresi logistik, maka perlu diuraikan rasionalitas pemilihan variabel bebas yang diduga berpengaruh kuat sebagai faktor atau karakteristik utama dalam membedakan rumah tangga miskin atau tidak miskin yang mencakup: daerah tempat tinggal, gender, jenjang pendidikan, usia, jumlah anggota rumah tangga, status bekerja. 
Daerah Tempat Tinggal

Daerah tempat tinggal/domisili rumahtangga daerah perkotaan dan perdesaan diduga berpengaruh terhadap pembentukan rumah tangga miskin/tidak miskin karena daerah perkotaan umumnya merupakan pusat pertumbuhan ekonomi yang memiliki fasilitas lebih lengkap dibandingkan perdesaan. Ketersediaan fasilitas ekonomi di perkotaan merupakan sarana kemudahan akses terhadap lapangan pekerjaan sebagai sumber pendapatan rumah tangga. Dengan demikian daerah perdesaan diduga merupakan daerah tempat tinggal/domisili yang bisa membentuk rumah tangga menjadi miskin dibanding daerah perkotaan.

Dalam penelitian yang dilakukan oleh Kutanegara (2000) pada studi kasus di Desa Sriharjo, Yogyakarta menyimpulkan bahwa perbedaan akses karena tempat tinggal mempengaruhi keberadaan rumah tangga miskin di suatu wilayah.

\section{Gender}

Jenis kelamin dianggap sebagai sesuatu yang berhubungan dengan aspek-aspek biologis seseorang yang melibatkan karakteristik perbedaan laki-laki dan perempuan berdasarkan kromosom, anatomi reproduksi, hormon, dan karakter fisiologis lainnya. Sedangkan gender melibatkan aspek-aspek sosiokultural yang dilekatkan pada laki-laki dan perempuan, yaitu apa yang didefinisikan masyarakat sebagai maskulinitas dan femininitas. (Rahman dan Nurhayati, 2004).

Studi eksplorasi tentang stereotipe gender yang dilakukan oleh William dan Best selama rentang tahun 1982, 1990, dan 1992 (Smith dan Bond, 1994) di tiga puluh kebudayaan yang berbeda mengindikasikan bahwa seratus mahasiswa laki-laki dan perempuan di tiap-tiap negara tersebut membuat semacam konsensus peran gender yang berbeda. Ternyata, laki-laki meyakini memiliki tipikal sifat yang tinggi dalam hal dominasi, otonomi, agresi, suka menonjolkan diri, prestasi tinggi, dan ketahanan mental yang luar biasa.

Gender kepala rumah tangga dibedakan laki-laki dan perempuan diduga berpengaruh terhadap pembentukan rumah tangga miskin atau tidak miskin. Kepala rumah tangga perempuan diduga lebih berpotensi bisa membentuk rumah tangga miskin daripada kepala rumah tangga lakilaki karena sifat pembawaan dari laki-laki secara psikologis lebih berani menghadapi risiko usaha daripada perempuan yang menjadi landasan kuat pengambilan keputusan dalam mengakses lapangan kerja sebagai sumber pendapatan rumah tangga.

\section{Jenjang Pendidikan}

Mengacu pada Undang-Undang Nomor 20 tentang Sistem Pendidikan Nasional Bab I Ketentuan Umum Pasal 1 ayat 8 menyatakan bahwa jenjang pendidikan adalah tahapan pendidikan yang ditetapkan berdasarkan tingkat perkembangan peserta didik, tujuan yang akan dicapai, dan kemampuan yang dikembangkan. Dalam Undang-Undang tersebut disebutkan bahwa jenjang pendidikan formal di Indonesia terdiri atas pendidikan dasar, pendidikan menengah, dan pendidikan tinggi.

Pendidikan Tinggi merupakan kelanjutan pendidikan menengah yang diselenggarakan untuk menyiapkan peserta didik menjadi anggota masyarakat yang memiliki kemampuan akademik dan profesional yang dapat menerapkan, mengembangkan dan menciptakan ilmu pengetahuan, teknologi dan atau kesenian.

Berdasarkan uraian pembagian jenjang pendidikan tersebut diatas, maka patut dikatakan bahwa semakin tinggi jenjang pendidikan seseorang akan membedakan kapasitas dan kapabilitas dalam kehidupan sosial, tak terkecuali urusan bisnis usaha. Oleh karenanya jenjang pendidikan diduga juga berpengaruh terhadap pembentukan rumah tangga miskin atau tidak miskin karena adanya perbedaan kapasitas dan kapabilitas jika dikaitkan dengan keberanian menghadapi risiko usaha yang menjadi landasan kuat pengambilan keputusan dalam mengakses lapangan pekerjaan sebagai sumber pendapatan rumah tangga.

Usia

Produktivitas seseorang dalam bekerja sangat dipengaruhi oleh faktor usia. 
Karakteristik pendapatan seseorang /individu adalah tingkat produktivitas kerja. Dengan demikian, usia kepala rumah tangga sangat menentukan tingkat pendapatan rumah tangga sehingga usia kepala rumah tangga diduga berpengaruh pada pembentukan rumah tangga miskin/tidak miskin. Hasil penelitian Putri dan Setiawina (2013) di desa Bebandem Karangasem menemukan bahwa umur merupakan variabel yang berpengaruh dominan terhadap pendapatan rumah tangga miskin.

\section{Jumlah Anggota Rumah Tangga}

Besar kecilnya jumlah anggota rumah tangga sangat menentukan jumlah pengeluaran/ konsumsi rumah tangga. Semakin besar jumlah anggota rumah tangga diduga berpengaruh terhadap pembentukan rumah tangga miskin.

\section{Status Bekerja}

Status bekerja seseorang/individu sangat menentukan tingkat pendapatannya.
Seseorang yang bekerja berpeluang memperoleh pendapatan atas usaha pekerjaannya. Sedangkan seseorang menganggur atau tidak bekerja maka tidak mempunyai pendapatan, kecuali dari transfer atau pinjam/hutang baru individu yang bersangkutan mempunyai pendapatan. Karena pendapatan berpengaruh kuat dalam pembentukan rumah tangga miskin, oleh karena itu status bekerja diduga mempengaruhi pembentukan rumah tangga miskin.

\section{HASIL DAN PEMBAHASAN}

\section{Model Regresi Logistik Kemiskinan Rumah Tangga}

Hasil regresi logistik Kemiskinan RumahTangga menurut variabel bebas daerah tempat tinggal, gender, jenjang pendidikan, usia, jumlah anggota rumah tangga, dan status bekerja dapat dilihat pada Tabel 1.

Tabel 1. Hasil Regresi Logistik Kemiskinan Rumah Tangga menurut Variabel bebas Gender, Usia, Pendidikan, Daerah Tempat Tinggal, Jumlah Anggota Rumah Tangga, dan Status Bekerja

\begin{tabular}{|c|c|c|c|c|c|c|c|c|}
\hline Variabel bebas & & Notasi & B & S.E. & Wald & Df & Sig. & $\operatorname{Exp}(B)$ \\
\hline (1) & & (2) & (3) & (4) & (5) & (6) & (7) & (8) \\
\hline $\begin{array}{l}\text { Jenis Kelamin } \\
\text { Kepala Rumah } \\
\text { tangga Perempuan }\end{array}$ & \multirow{7}{*}{$\begin{array}{l}\text { Step } \\
1^{\mathrm{a}}\end{array}$} & $\mathrm{JK}(1)$ & $-0,356$ & 0,062 & 32,912 & 1 & 0,000 & 0,701 \\
\hline $\begin{array}{l}\text { Usia Tua (60 tahun } \\
\text { ke atas) }\end{array}$ & & umur(1) & 0,509 & 0,158 & 10,305 & 1 & 0,001 & 1,663 \\
\hline $\begin{array}{l}\text { Jenjang Pendidikan } \\
\text { SD ke bawah }\end{array}$ & & $\operatorname{didik}(1)$ & 1,687 & 0,156 & 117,136 & 1 & 0,000 & 5,402 \\
\hline Daerah Perdesaan & & DTT(1) & 0,335 & 0,045 & 55,510 & 1 & 0,000 & 1,398 \\
\hline $\begin{array}{l}\text { Pendidikan SD ke } \\
\text { bawah dan Usia } 60+\end{array}$ & & $\begin{array}{l}\operatorname{didik}(1) \text { by } \\
\text { umur(1) }\end{array}$ & $-0,920$ & 0,165 & 30,979 & 1 & 0,000 & 0,398 \\
\hline $\begin{array}{l}\text { Jumlah Anggota } \\
\text { rumah tangga } 5 \text { ke } \\
\text { atas dan KRT Tidak } \\
\text { Bekerja }\end{array}$ & & $\begin{array}{l}\text { JART(1) } \\
\text { by } \\
\text { bekerja(1) }\end{array}$ & 0,768 & 0,103 & 55,321 & 1 & 0,000 & 2,156 \\
\hline Konstanta & & & $-3,594$ & 0,152 & 556,065 & 1 & 0,000 & 0,027 \\
\hline
\end{tabular}


Sehingga model regresi logisitik yang dihasilkan adalah sebagi berikut:

$$
\log \left(\frac{p_{i}}{1-p_{i}}\right)_{i}=-3,594-0,356 X_{1 i}+0,509 X_{2 i}+1,687 X_{3 i}
$$

Dari tabel 1 menunjukkan bahwa Nilai Chi Square sebesar 8,284 dan dengan nilai signifikasi sebesar 0,000 sehingga dapat dikatakan bahwa model sesuai dengan kondisi data sehingga model dapat digunakan untuk analisis lebih lanjut.

Berdasarkan 6 variabel yang diajukan, yaitu gender, usia, jenjang pendidikan, daerah tempat tinggal, jumlah anggota rumah tangga, dan status bekerja kepala rumah tangga maka diperoleh hasil sebagai berikut:

\section{Daerah Tempat Tinggal}

Variabel tempat tinggal menghasilkan nilai Wald 55,510 dan signifikansi 0,000 yang berarti bahwa variabel tempat tinggal dapat menjadi faktor penentu probabilitas menjadi miskin. Nilai Odds rasio variabel tempat tinggal adalah 1,398 yang berarti bahwa rumah tangga yang tinggal di daerah perdesaan mempunyai peluang untuk menjadi miskin 1,398 kali lebih tinggi dibandingkan rumah tangga yang tinggal di daerah perkotaan. Tidak merata dan tidak samanya akses bagi semua penduduk terhadap sumber daya yang ada telah menyebabkan masih banyaknya penduduk miskin di perdesaan, hal ini senada dengan hasil penelitian Kutanegara pada studi kasus di Desa Sriharjo, Yogyakarta.

\section{Gender}

Nilai Wald variabel jenis kelamin adalah 32,912 dengan p_value sebesar 0,000 sehingga dapat dikatakan bahwa variabel jenis kelamin mempunyai pengaruh terhadap probalitas rumah tangga menjadi miskin. Nilai Odds rasio sebesar 0,701 menunjukkan bahwa probabilitas kepala rumah tangga perempuan untuk menjadi miskin justru 0,701 kali lebih rendah dibandingkan rumah tangga yang dikepalai oleh laki-laki. Penelitian Indraswari (2009) justru menyimpulkan bahwa kaum perempuan menjadi kelompok termiskin dan mencerminkan kuatnya budaya patriarki yang menomorduakan perempuan.
Dalam kasus penelitian ini, hanya karakteristik kepala rumah tangga yang dimasukkan, oleh karena itu, masih ada faktor lain yang berpengaruh terhadap miskin tidaknya rumah tangga, yaitu anggota rumah tangga. Pendapatan rumah tangga yang dikepalai perempuan tidak mutlak seluruhnya berasal dari kepala rumah tangga melainkan juga berasal dari anggota rumah tangga yang sudah dewasa.

\section{Usia}

Nilai p-value untuk variabel jenis kelamin adalah 0,001 sehingga dapat dikatakan bahwa variabel umur mempunyai pengaruh terhadap probalilitas rumah tangga menjadi miskin. Nilai Odds rasio sebesar 1,663 menunjukkan bahwa probabilitas kepala rumah tangga yang berumur 60 tahun atau lebih untuk menjadi miskin 1,663 lebih tinggi dibandingkan rumah tangga yang dikepalai oleh kepala rumah tangga yang berumur kurang dari 60 tahun. Hal ini diduga karena usia kurang dari 60 tahun merupakan usia produktif yang masing mempunyai banyak potensi untuk bekerja dan berusaha dibandingkan kepala rumah tangga yang sudah lanjut usia.

\section{Jenjang Pendidikan}

Variabel pendidikan menghasilkan nilai Wald 117,136 dan signifikansi 0,000 yang berarti bahwa variabel pendidikan dapat menjadi faktor penentu probabilitas menjadi miskin. Nilai Odds rasio variabel pendidikan adalah 5,402 yang berarti bahwa rumah tangga dengan tingkat pendidikan SD ke bawah mempunyai peluang untuk menjadi miskin 5,402 kali lebih tinggi dibandingkan rumah tangga dengan kepala rumah tangga yang berpendidikan SMP ke atas.

Hasil penelitian Didu dan Fauzi (2016) di Kabupaten Lebak memberikan hasil bahwa semakin tinggi tingkat pendidikan maka semakin rendah tingkat kemiskinan. Dengan demikian, secara tidak langsung pendidikan yang tinggi akan mengurangi risiko seseorang menjadi miskin. 


\section{Variabel Interaksi Pendidikan Dan Usia}

Dengan melihat nilai korelasi antara variabel pendidikan dan usia maka dilakukan interaksi antara variabel pendidikan dan usia. Variabel interaksi ini menghasilkan nilai Wald sebesar 30,979 dan signifikasi p_value 0,000 . Nilai Odds rasio yang dihasilkan adalah 0,398 yang berarti bahwa rumah tangga dengan kepala rumah tangga yang berpendidikan rendah dan berusia 60 tahun atau lebih justru mempunyai peluang untuk menjadi miskin 0,398 kali lebih rendah.

\section{Variabel Interaksi Jumlah Anggota}

Rumah Tangga Dan Status Bekerja Kepala Rumah Tangga

Pembentukan variabel interaksi antara jumlah anggota rumah tangga dan status kepala rumah tangga dilakukan karena masing-masing variabel secara independent tidak berpengaruh langsung terhadap probabilitas menjadi miskin. Variabel interaksi menghasilkan nilai signifikansi 0,000 yang berarti ketika variabel jumah anggota rumah tangga diinteraksikan dengan status bekerja kepala rumah tangga dapat mempengaruhi probabilitas menjadi miskin. Nilai Odds rasio sebesar 2,156 berarti bahwa rumah tangga dengan jumlah anggota rumah tangga 5 orang atau lebih dan kepala rumah tangga tidak bekerja mempunyai peluang 2,156 kali lebih besar dibanding rumah tangga dengan jumlah anggota rumah tangga lebih sedikit atau kepala rumah tangga yang bekerja.

Hasil penelitian ini sesuai dengan penelitian yang dilakukan oleh Sa'diyah dan Arianti (2012), bahwa hubungan antara pendidikan dan kemiskinan adalah negatif, yaitu semakin banyak jumlah anggota keluarga maka semakin kecil pendapatan keluarga yang mengindikasikan semakin miskin.

\section{KESIMPULAN DAN REKOMENDASI}

\section{Kesimpulan}

Dari hasil penelitian ditemukan beberapa hal sebagai berikut:

a. Ada 6 (enam) karakteristik utama, yaitu: daerah tempat tinggal, gender, jenjang pendidikan, jumlah anggota rumah tangga dan status bekerja kepala rumah tangga, yang berpotensi menyebabkan rumah tangga miskin di Jawa Tengah

b. Rumah tangga yang tinggal di daerah perdesaan mempunyai peluang untuk menjadi miskin 1,398 kali lebih tinggi dibandingkan rumah tangga yang tinggal di daerah perkotaan.

c. Probabilitas kepala rumah tangga perempuan untuk menjadi miskin justru 0,701 kali lebih rendah dibandingkan rumah tangga yang dikepalai oleh lakilaki. Ini karena pendapatan rumah tangga yang dikepalai perempuan tidak mutlak seluruhnya berasal dari kepala rumah tangga melainkan juga berasal dari anggota rumahtangga yang sudah dewasa.

d. Rumah tangga dengan kepala rumah tangga dengan tingkat pendidikan SD ke bawah mempunyai peluang menjadi miskin 5,402 kali lebih tinggi dibandingkan rumah tangga dengan kepala rumah tangga yang berpendidikan SMP ke atas.

e. Rumah tangga dengan kepala rumah tangga yang berpendidikan rendah dan berusia 60 tahun atau lebih justru mempunyai peluang untuk menjadi miskin 0,398 kali lebih rendah. Kondisi ini diduga karena struktur anggota rumah tangga yang bekerja. Kepala rumah tangga yang berpendidikan rendah dan berusia 60 tahun atau lebih cenderung tidak produktif sehingga penghasilan utama justru dari anggota rumah tangga yang bekerja.

\section{Rekomendasi}

Berdasarkan kesimpulan tersebut, maka disarankan:

a. Salah satu langkah awal untuk dapat mengantisipasi kemiskinan adalah dengan mengetahui karateristik kemiskinan itu sendiri. Pendidikan dan daerah tempat tinggal merupakan karakteristik utama rumah tangga miskin yang dapat diintervensi oleh pemerintah dalam rangka penurunan kemiskinan di Jawa Tengah. Prioritas pembangunan dengan mengedepankan 
wilayah perdesaan sangat penting dalam penurunan kemiskinan di wilayah perdesaan. Memperbaiki kualitas pendidikan penduduk terutama di perdesaan dengan menanamkan kesadaran pentingnya pendidikan serta keterampilan berwirausaha menjadi faktor penting dalam memutus rantai kemiskinan di Jawa Tengah. Selain itu, jumlah anggota rumah tangga yang besar juga memberikan risiko lebih besar untuk menjadi miskin, oleh karena itu program kependudukan dengan pembatasan kelahiran pada keluarga tertentu menjadi penting untuk dipertimbangkan kembali.

b. Perlu dilakukan pengkajian lebih lanjut mengenai karakteristik kemiskinan rumah tangga dengan menyertakan variabel ekonomi, seperti jumlah anggota rumah tangga yang bekerja serta lapangan pekerjaan.

\section{DAFTAR PUSTAKA}

Asra, A., Utomo, A.P., Asikin, M., dan Pusponegoro, N.H. 2017. Analisis Multivariabel: Suatu Pengantar. Bogor: In Media.

Bappenas. 2000. Program Pembangunan Nasional Penanggulangan Kemiskinan. Makalah dalam diskusi Rapat Koordinasi Kelompok Kerja Operasional Gerakan Terpadu Pengentasan Kemiskinan Tingkat Pusat, Jakarta 13 Juni 2000.

Didu, S., dan Fauzi, F. 2016. Pengaruh Jumlah Penduduk, Pendidikan Dan Pertumbuhan Ekonomi Terhadap Kemiskinan Di Kabupaten Lebak. Jurnal Ekonomi, Vol. 6 (1), 100-114.

Erwandari, N. 2017. Implementasi Sustainable Development Goals (SDG's) dalam Meningkatkan Ketahanan Pangan di Provinsi Riau. eJournal Ilmu Hubungan Internasional, 5(3), 875-888.

Rahman, F., dan Nurhayati, S.R. 2004. Model Pendampingan Psikologis Berbasis Gender dalam Kasus Kekerasan terhadap Perempuan. Jurnal Online Universitas Negeri Yogyakarta.
Gujarati, D.N. 2003. Basic Econometrics. Fourth Edition. New York: The McGraw-Hill Companies.

Indraswari. 2009. Perempuan dan Kemiskinan. Jurnal Analisis Sosial, Vol. 14 (2), 40-52.

Kutanegara, P.M. 2000. Akses Terhadap Sumber Daya dan Kemiskinan di Pedesaan Jawa: Kasus Desa Sriharjo, Yogyakarta. Humaniora, Volume XII, No. 3.

Putri, A.D., dan Setiawina, N.D. 2013. Pengaruh Umur, Pendidikan, Pekerjaan Terhadap Pendapatan Rumah Tangga Miskin di Desa Bebandem. E-Jurnal Ekonomi Pembangunan Universitas Udayana, Vol. 2 (4), 173-180.

Sa'diyah, Y.H., dan Arianti, F. 2012. Analisis Kemiskinan Rumahtangga Melalui Faktor-faktor yang Mempengaruhinya di Kecamatan Tugu Kota Semarang. Diponegoro Journal of Economics, Volume 1, Nomor 1.

Smith dan Bond, 1994. Cross-Cultural Social and Organizational Psychology. Annu. Rev. Psychol, Vol 47, 205-235.

Todaro, M.P. 2003. Economic Development. The George Washington University.

United Nations. 2015. The Millennium Development Goals Report 2015. United Nations. NewYork, 2015. 